\title{
Vitamin D receptor FokI, BsmI, ApaI, and TaqI polymorphisms and the susceptibility to breast cancer: a meta-analysis
}

\author{
Y. H. LEE ${ }^{*}$, G. G. SONG \\ Division of Rheumatology, Department of Internal Medicine, Korea University College of Medicine, Korea University Medical Center, \\ Seoul, Korea
}

*Correspondence: lyhcgh@korea.ac.kr

Received December 31, 2013 / Accepted March 10, 2014

\begin{abstract}
The goal of this study is to examine whether vitamin D receptor (VDR) polymorphisms are associated with the susceptibility to breast cancer.

Meta-analysis was employed to investigate the association between the VDR FokI, BsmI, ApaI, and TaqI polymorphisms and the incidence of breast cancer.

A total of 32 comparative studies were evaluated in this meta-analysis, which included 17,067 patients and 20,843 controls. Meta-analysis of the VDR FokI polymorphism indicated an association between the incidence of breast cancer and the ff genotype in Europeans ( $\mathrm{OR}=1.126,95 \% \mathrm{CI}=1.026-1.243, p=0.019)$ Furthermore, an association between the incidence of breast cancer and the VDR FokI polymorphism was found in the Europeans using the allele contrast, as well as the homozygote contrast. However, the meta-analysis indicated no association between breast cancer and the BsmI polymorphism in all study subjects, including the Europeans (OR for the B allele $=0.996,95 \% \mathrm{CI}=0.964-1.097, p=0.930,1.026,95 \% \mathrm{CI}=$ $0.929-1.134, p=0.610)$. Moreover, breast cancer incidence was not associated with the ApaI and Taq polymorphisms (OR for the A allele $=0.908,95 \% \mathrm{CI}=0.763-1.041, p=0.167$, OR for the T allele $=0.972,95 \% \mathrm{CI}=0.929-1.017, p=0.221$ )

This meta-analysis suggests that the VDR FokI polymorphism is associated with susceptibility to breast cancer in the European population.
\end{abstract}

Key words: breast cancer, vitamin D receptor, polymorphism, meta-analysis

Breast cancer, the most common cancer worldwide, accounts for $22.9 \%$ of the invasive cancers and is associated with the highest fatality rates in women. Although the etiology of breast cancer is unclear, both genetic and environmental factors are considered to contribute to its development [1].

Although the primary function of vitamin $\mathrm{D}$ involves the maintenance of bone mineral homeostasis, it is also involved in interleukin (IL)-2 inhibition, antibody production, and lymphocyte proliferation [2]. It has been reported that 1,25 -dihydroxy vitamin $\mathrm{D}_{3}\left(1,25(\mathrm{OH})_{2} \mathrm{D}_{3}\right)$ inhibits interferon secretion and negatively regulates IL-12 production by downregulating nuclear factor-kappaB [3]. In addition, vitamin $\mathrm{D}$ plays a critical regulatory role in the differentiation and proliferation of cancer cells by influencing cell cycle regulation [4]. Studies suggest that exposure to sunlight may reduce the risk of breast cancer in addition to increasing the production of vitamin $\mathrm{D}$ in the skin, as vitamin $\mathrm{D}$ inhibits growth and induces apoptosis in the breast cancer cells [5]. Thus, vitamin D may play a pivotal role in the development of breast cancer.

The activity of vitamin $\mathrm{D}$ is dependent on the vitamin $\mathrm{D}$ receptor (VDR), a member of the nuclear hormone receptor superfamily. The VDR gene is one of the most frequently studied genes with respect to breast cancer. It is located on the chromosome 12q13.11 [6], and 3 polymorphisms, BsmI (rs1544410), ApaI (rs7975232) (both in intron 8), and TaqI (rs731236) (in exon 9), have been identified at the 3 '-end of the gene, and shown to be in strong linkage of disequilibrium (LD) [7]. The other polymorphic region, FokI (rs2228570), is located in the start codon [6]. Although the functional significance of these 4 polymorphisms remains unknown, it is believed that LD and one or more functional polymorphisms elsewhere in the VDR gene contribute to the observed association between the polymorphisms of the VDR gene 
and some cancers. Although these VDR polymorphisms have been linked to breast cancer development in several reports, failed to find an association [8-31]. This may be due to small sample sizes, low statistical power, and/or clinical heterogeneity [32-34] in these studies. In order to overcome the limitations of individual studies, resolve inconsistencies, and reduce the likelihood that random errors are responsible for false-positive or false-negative associations, we employed a meta-analysis. Therefore, the present study aims to determine whether the VDR FokI, BsmI, ApaI, and TaqI polymorphisms are associated with the susceptibility to breast cancer, using meta-analysis.

\section{Materials and methods}

Identification of eligible studies and data extraction. We performed a search for studies that examined the association between VDR polymorphisms and breast cancer. A literary search using the MEDLINE citation database was used to identify available articles in which VDR polymorphisms were analyzed in breast cancer patients (until June 2013). Combinations of keywords, such as 'vitamin D,' 'VDR,' 'polymorphism,' and 'breast cancer' were entered as Medical Subject Headings $(\mathrm{MeSH})$ or text words. References in the identified studies were also investigated to identify additional studies not indexed by MEDLINE. No language or country restrictions were applied. Studies were included if (1) they were case-control studies, (2) the data were original (independent of other studies), (3) they provided enough data to calculate an odds ratio (OR), and (4) they showed a distribution of the VDR polymorphism in normal controls that was consistent with $\mathrm{H}-\mathrm{W}$ equilibrium. Studies were excluded if: (1) they contained overlapping data; (2) the number of genotypes could not be ascertained; and (3) the family members were also included in the study, as these analyses are based on linkage considerations. Data were extracted from the original studies by 2 independent reviewers, following the specified selection criteria for the meta-analysis. Any discrepancies between the reviewer observations were resolved by a consultation with a third reviewer. The extracted information from each study included the author, year of publication, ethnicity of the study population, demographics, and the number of cases and controls for each of the FokI, BsmI, ApaI, and TaqI genotypes. Frequencies of the alleles were calculated from the corresponding distribution of the genotypes.

Evaluations of statistical associations. We performed meta-analyses using: 1) allelic contrast, 2) contrast of homozygotes, 3) recessive, and 4) dominant models. Point estimates of risk, ORs, and 95\% confidence intervals (CI) were estimated for each study. In addition, within- and between-study variations or heterogeneities were assessed using Cochran's Q-statistic. This heterogeneity test assesses the null hypothesis that all studies evaluated have the same effect. The effect of heterogeneity was quantified using $\mathrm{I}^{2}$, which ranges between $0 \%$ and $100 \%$, and represents the proportion of between-study variability that can be attributed to heterogeneity rather than chance [35]. $\mathrm{I}^{2}$ values of $25 \%, 50 \%$, and $75 \%$ were nominally assigned as low, moderate, and high estimates. The fixed effects model assumes that the effect of genetic factors on breast cancer susceptibility across all studies investigated is similar, and that the observed variations among studies are caused by chance alone [36]. The random effects model assumes that different studies show substantial diversity and assesses both the within-study sampling error and between-study variance [37]. When study groups are homogeneous, the use of the fixed or random effect models generates similar results, and when this is not the case, the random effect model usually provides wider CIs than the fixed effect model. The random effect model is used in the presence of significant betweenstudy heterogeneity [37]. The statistical analyses were done using a comprehensive meta-analysis computer program (Biosta, Englewood, NJ, USA).

Evaluation of publication bias. Funnel plots are often used to detect publication bias. However, due to the limitations of funnel plotting, which requires a range of studies of varying sizes involving subjective judgments, publication bias was evaluated using Egger's linear regression test [38], which measures funnel plot asymmetry using a natural logarithm scale of the odds ratios (OR).

\section{Results}

Studies included in the meta-analysis. Sixty-seven studies were identified by electronic and manual searches and 30 were selected for a full-text review based on their title and abstract details [39-53]. Of these 30 studies, 6 studies were excluded as 4 were not in HWE [48-51] and 2 did not include the data on the VDR polymorphisms [52, 53]. Thus, 24 studies met the inclusion criteria [8-31] (Figure 1). Of the eligible studies, 4 contained data on 2 different groups $[8,16,18,30]$, and 1 had data on 5 different groups [17], and these were treated independently. Thus, a total of 32 separate comparisons were considered in the meta-analysis, which included $17,067 \mathrm{pa}-$ tients and 20,843 controls in total (Table 1). These 32 studies encompassed 20 Europeans, 2 Asians, 2 African Americans, 2 Hispanics, 2 mixed-race subjects, 1 Arab, 1 Indian, 1 Hawaiian, and one of unknown ethnicity. Thus, an ethnicity-specific meta-analysis was conducted for the European population. The VDR FokI polymorphism was examined by 18 studies, the BsmI polymorphism by 15 , the ApaI polymorphism by 8 , and the TaqI polymorphism by 15 . Selected characteristics of these studies with respect to the association between the VDR polymorphisms and breast cancer are summarized in Table 1.

Meta-analysis of the association between the VDR FokI polymorphism and breast cancer. A summary of the metaanalysis, indicating the association between the VDR FokI and BsmI polymorphisms and breast cancer, is presented in Table 2. Meta-analysis of the VDR FokI polymorphism showed an association between the incidence of breast cancer and the ff 


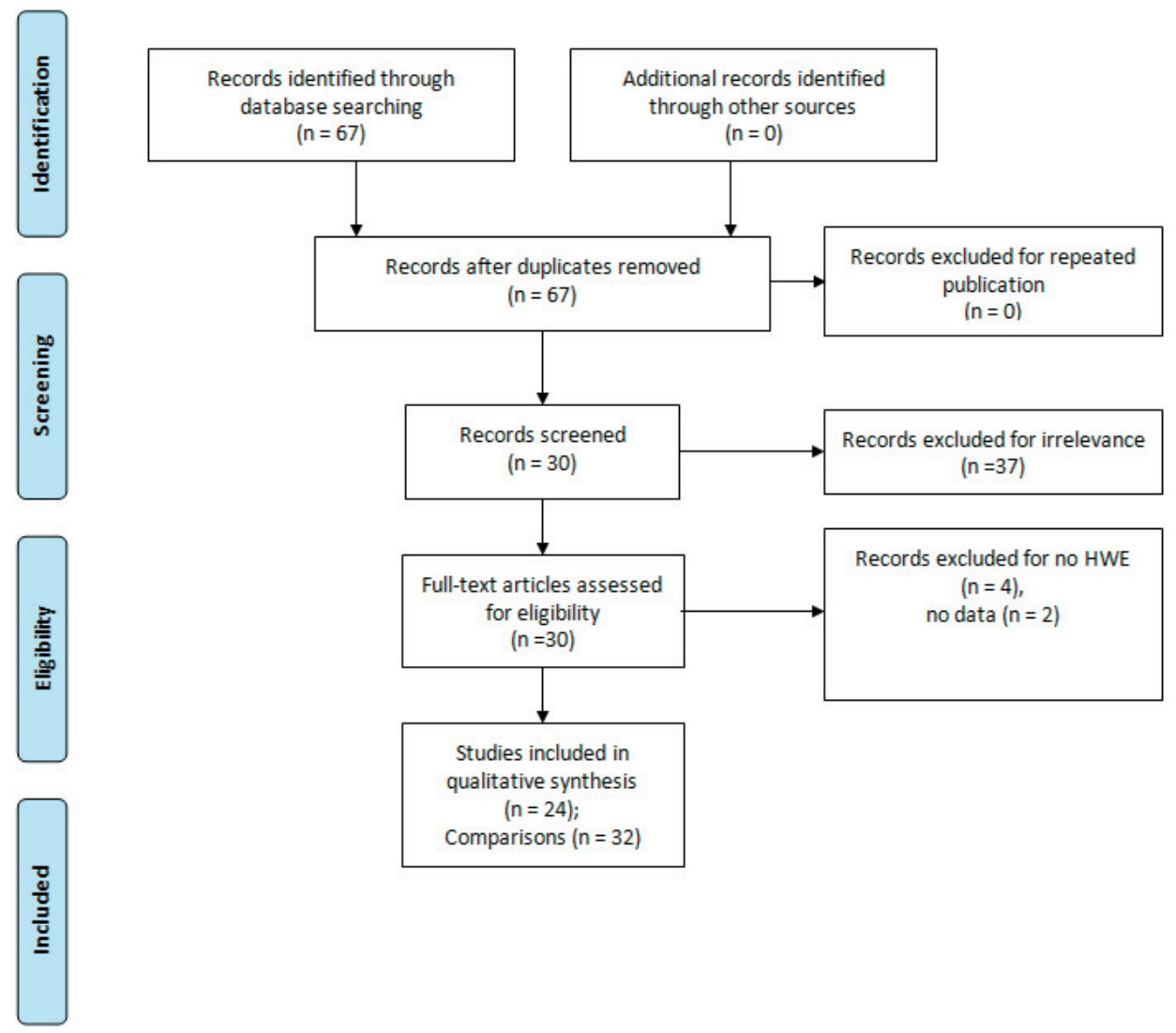

Figure 1. Flow chart illustrating the study design.

genotype in all study subjects $(\mathrm{OR}=1.089,95 \% \mathrm{CI}=$ $1.010-1.175, p=0.026$ ) (Table 2, Figure 2). Stratification by ethnicity revealed a significant association between the VDR FokI ff genotype and breast cancer in Europeans $(\mathrm{OR}=1.126,95 \% \mathrm{CI}=1.026-1.243, p=$ 0.019 ) (Table 2). Furthermore, this association in the European cohort between breast cancer incidence and the VDR FokI polymorphism was revealed by the use of both the allele contrast, as well as homozygote contrast (Table 2).

Meta-analysis of the association between the VDR BsmI, ApaI and TaqI polymorphisms and breast cancer. Meta-analysis revealed no association between breast cancer and the BsmI B allele in all study subjects $(\mathrm{OR}=0.996,95 \% \mathrm{CI}=0.964-1.097, p=0.930)$ (Table 3). Stratification by ethnicity revealed no association between the BsmI B allele and breast cancer in Europeans $(\mathrm{OR}=1.026,95 \% \mathrm{CI}=0.929-1.134, p=0.610)$ (Table 3). The recessive and dominant models and homozygote contrast failed to reveal an association between the BsmI polymorphism and the incidence of breast cancer (Table 3, Figure 3). Meta-analysis of the VDR ApaI polymorphism showed no association be-

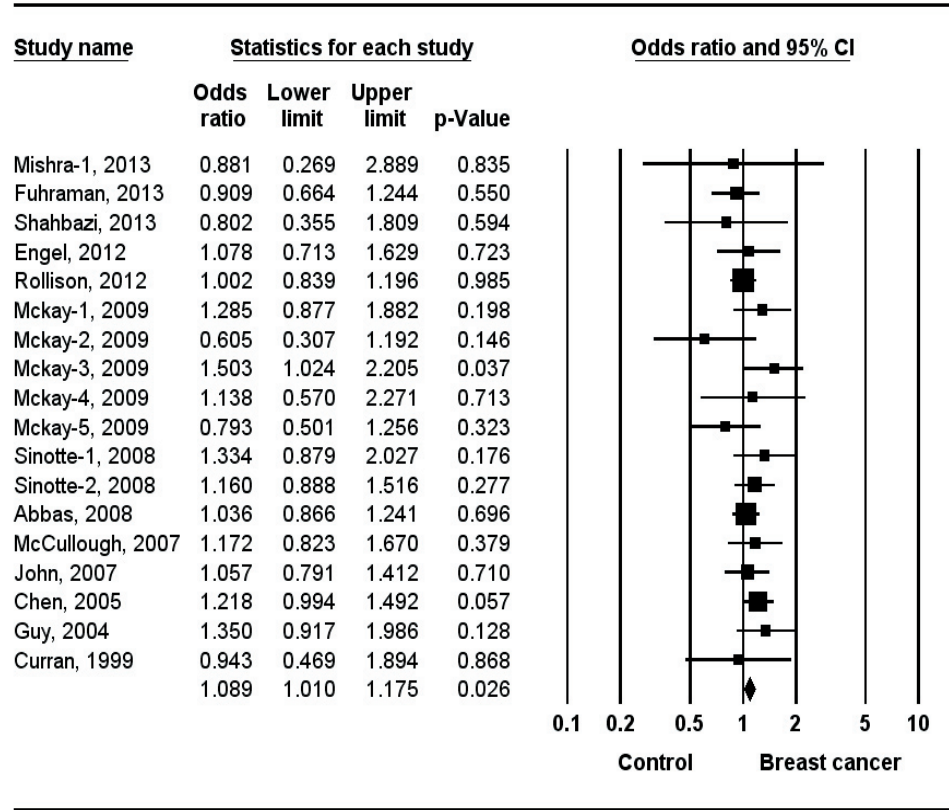

Figure 2. ORs and $\mathbf{9 5 \%}$ CIs of individual studies and pooled data for the association between breast cancer incidence and the VDR FokI polymorphism, under the recessive model. 
Table 1. Characteristics of individual studies included in the meta-analysis.

\begin{tabular}{|c|c|c|c|c|c|c|}
\hline \multirow{2}{*}{ Study [Ref] } & \multirow{2}{*}{ Country } & \multirow{2}{*}{ Ethnicity } & \multicolumn{2}{|c|}{ Numbers } & \multirow{2}{*}{ Polymorphism(s) } & \multirow{2}{*}{ Association findings } \\
\hline & & & Case & Control & & \\
\hline Mishra-1, 2013[8] & USA & African American & 115 & 73 & FokI', BsmI, ApaI, TaqI & NS \\
\hline Mishra-2, 2013[8] & USA & Hispanic & 117 & 276 & FokI, BsmI, ApaI*, TaqI & NS \\
\hline Fuhrman, 2013[9] & USA & Unkonwn & 484 & 845 & FokI, BsmI & FokI (NS), BsmI $(\mathrm{p}=0.02)$ \\
\hline Shahbazi, 2013[10] & Iran & Arab & 140 & 156 & FokI, BsmI & FokI (NS), BsmI $(\mathrm{p}=0.01)$ \\
\hline Engel, 2012[11] & USA & European & 270 & 554 & FokI, ApaI, TaqI* & NS \\
\hline Dalessandri, 2012[12] & USA & European & 164 & 174 & ApaI & NS \\
\hline Rollison, 2012[13] & USA & Mixed & 2,318 & 2,521 & FokI, BsmI ${ }^{*}$ & NS \\
\hline Anderson, 2011[14] & Canada & European & 1,777 & 1,839 & FokI ${ }^{\star}$, BsmI, ApaI, TaqI & NS \\
\hline Chakraborty, 2009[15] & Inida & Indian & 160 & 140 & ApaI, TaqI & NS \\
\hline Gapska-1, 2009[16] & Poland & European & 960 & 960 & BsmI, TaqI & NS \\
\hline Gapska-2, 2009[16] & Poland & European & 800 & 550 & BsmI, TaqI & NS \\
\hline McKay-1, 2009[17] & USA & Hispanic & 318 & 378 & FokI & NS \\
\hline McKay-2, 2009[17] & USA & African American & 325 & 419 & FokI & NS \\
\hline McKay-3, 2009[17] & USA & Asian & 401 & 405 & FokI & NS \\
\hline McKay-4, 2009[17] & USA & Hawaian & 104 & 278 & FokI & NS \\
\hline McKay-5, 2009[17] & USA & European & 378 & 421 & FokI & NS \\
\hline Sinotte-1, 2008[18] & Canada & European & 225 & 463 & FokI, BsmI & NS \\
\hline Sinotte-2, 2008[18] & Canada & European & 622 & 974 & FokI, BsmI & NS \\
\hline Abbas, 2008[19] & Germany & European & 1,408 & 2,612 & FokI, TaqI & NS \\
\hline McCullough, 2007[20] & USA & European & 500 & 500 & FokI, BsmI, ApaI, TaqI & NS \\
\hline John, 2007[21] & USA & Mixed & 1,786 & 2,127 & FokI, TaqI & NS \\
\hline Lowe, $2005[22]$ & $\mathrm{UK}$ & European & 179 & 179 & BsmI & NS \\
\hline Chen, 2005[23] & Turkey & European & 1,234 & 1,676 & FokI & NS \\
\hline Sillanpaa, 2004[24] & Finland & European & 483 & 482 & ApaI, TaqI & NS \\
\hline Guy, 2004[25] & UK & European & 398 & 427 & FokI, BsmI & NS \\
\hline Buyru, 2003[26] & Turkey & European & 27 & 78 & BsmI, TaqI $^{*}$ & NS \\
\hline Hou, 2002[27] & Taiwan & Asian & 34 & 169 & BsmI, ApaI, TaqI & NS \\
\hline Ingles, $2000[28]$ & USA & European & 143 & 300 & BsmI & NS \\
\hline Lundin, 1999[29] & Sweden & European & 111 & 130 & TaqI & NS \\
\hline Dunning-1, 1999[30] & UK & European & 211 & 268 & TaqI & NS \\
\hline Dunning-2, 1999[30] & $\mathrm{UK}$ & European & 740 & 359 & TaqI & NS \\
\hline Curran, 1999[31] & Australia & European & 135 & 110 & FokI, ApaI, TaqI & NS \\
\hline
\end{tabular}

Ref, reference; NS, not significant; UK, United Kingdom; USA, United States of America; 'control genotypes not in Hardy-Weinberg equilibrium.

Table 2. Meta-analysis of the association between breast cancer incidence and the VDR FokI polymorphism.

\begin{tabular}{|c|c|c|c|c|c|c|c|c|}
\hline \multirow[t]{2}{*}{ Polymorphism } & \multirow[t]{2}{*}{ Population } & \multirow[t]{2}{*}{ No. of studies } & \multicolumn{3}{|c|}{ Test of association } & \multicolumn{3}{|c|}{ Test of heterogeneity } \\
\hline & & & OR & $95 \% \mathrm{CI}$ & $p$-val & Model & $p$-val & $I^{2}$ \\
\hline \multirow{2}{*}{ FokI f vs. F } & Overall & 18 & 1.033 & $0.994-1.074$ & 0.099 & $\mathrm{~F}$ & 0.270 & 15.3 \\
\hline & European & 9 & 1.057 & $1.004-1.114$ & 0.034 & $\mathrm{~F}$ & 0.186 & 29.0 \\
\hline \multirow{2}{*}{ ff vs. Ff + FF (recessive) } & Overall & 18 & 1.089 & $1.010-1.175$ & 0.026 & $\mathrm{~F}$ & 0.588 & 0 \\
\hline & European & 9 & 1.126 & $1.020-1.243$ & 0.019 & $\mathrm{~F}$ & 0.704 & 0 \\
\hline \multirow{2}{*}{$\mathrm{ff}+\mathrm{Ff}$ vs. FF (dominant) } & Overall & 18 & 1.019 & $0.965-1.077$ & 0.490 & $\mathrm{~F}$ & 0.354 & 8.40 \\
\hline & European & 9 & 1.048 & $0.974-1.128$ & 0.212 & $\mathrm{~F}$ & 0.138 & 34.9 \\
\hline \multirow{2}{*}{ ff vs. FF } & Overall & 18 & 1.086 & $1.000-1.178$ & 0.049 & $\mathrm{~F}$ & 0.305 & 12.4 \\
\hline & European & 9 & 1.141 & $1.024-1.271$ & 0.017 & $\mathrm{~F}$ & 0.350 & 10.2 \\
\hline
\end{tabular}

$V D R$, vitamin D receptor; $O R$, odds ratio; $C I$, confidence interval; $R$, Random effects model; $F$, Fixed effects model. 
tween breast cancer and the A allele in all study subjects (OR $=0.908,95 \%$ CI $=0.763-1.041, p=0.167)$ (Table $3)$. Stratification by ethnicity revealed no association between the ApaI A allele and the incidence of breast cancer in Europeans $(\mathrm{OR}=0.934,95 \% \mathrm{CI}=0.818-1.067$, $p=0.317$ ) (Table 3). Furthermore, no association was found between breast cancer and VDR ApaI polymorphism using other genetic models (Table 3, Figure 3). Meta-analysis indicated no association between breast cancer and the TaqI T allele in either the overall study population or the European population $(\mathrm{OR}=0.972$, $95 \% \mathrm{CI}=0.929-1.017, p=0.221$ and $\mathrm{OR}=0.974,95 \%$ $\mathrm{CI}=0.928-1.023, p=0.294$, respectively) (Table 3 ). The recessive and dominant models and homozygote contrast failed to reveal an association between the TaqI polymorphism and breast cancer incidence (Table 3, Figure 3).

Heterogeneity and publication bias. Some heterogeneity was observed in the meta-analysis of the VDR BsmI and ApaI polymorphisms, but between-study heterogeneity was not found during the meta-analysis of the VDR FokI and TaqI polymorphisms (Table 2, and 3). It was difficult to correlate the funnel plot, which is usually used to detect publication bias, as the number of studies included in the analysis was relatively small. However, Egger's regression test showed no evidence of publication bias (Egger's regression test $p$-values > 0.1) (Figure 4).

\section{Discussion}

Vitamin D regulates the processes of cellular proliferation, differentiation, and apoptosis, which influence cancer development. Since VDR polymorphisms have been reported to be associated with the development of several cancers [54], they could be considered as a risk factor for breast cancer development.

In this meta-analysis, we combined data from published studies to evaluate the genetic association between the most commonly studied polymorphisms of the VDR gene, namely, the FokI, BsmI, ApaI, and TaqI polymorphisms and the incidence of breast cancer. Our meta-analysis of the VDR BsmI, ApaI, and TaqI polymorphisms showed no association with breast cancer in all study subjects including the European sub-group. In contrast, the meta-analysis of the FokI polymorphism revealed a significant association between breast cancer and the $\mathrm{f}$ allele in the European population $(\mathrm{OR}=$ $1.057,95 \% \mathrm{CI}=1.004-1.114, p=0.034)$. In addition, the meta-analysis using the recessive model and the homozygote contrast found an association of this allele with breast cancer incidence in the European population. Our meta-analysis suggests that the VDR FokI f allele may be a risk factor for breast cancer development in Europeans.
A

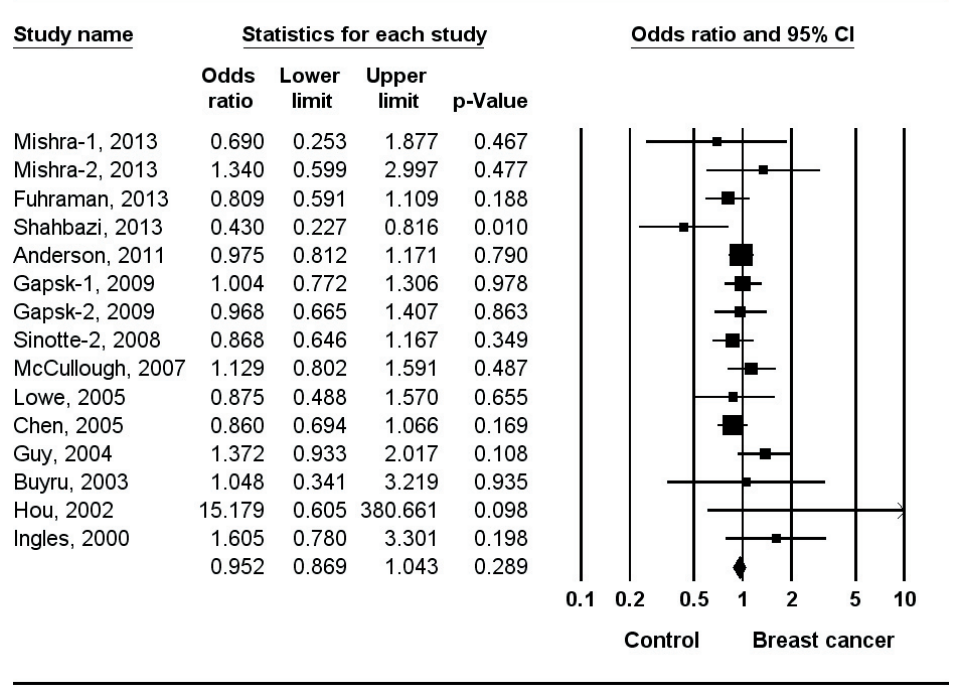

B

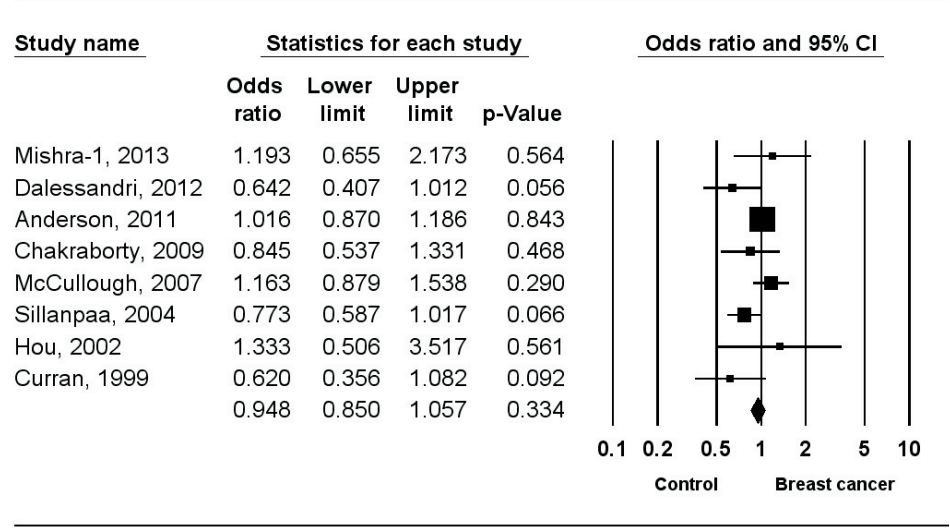

C

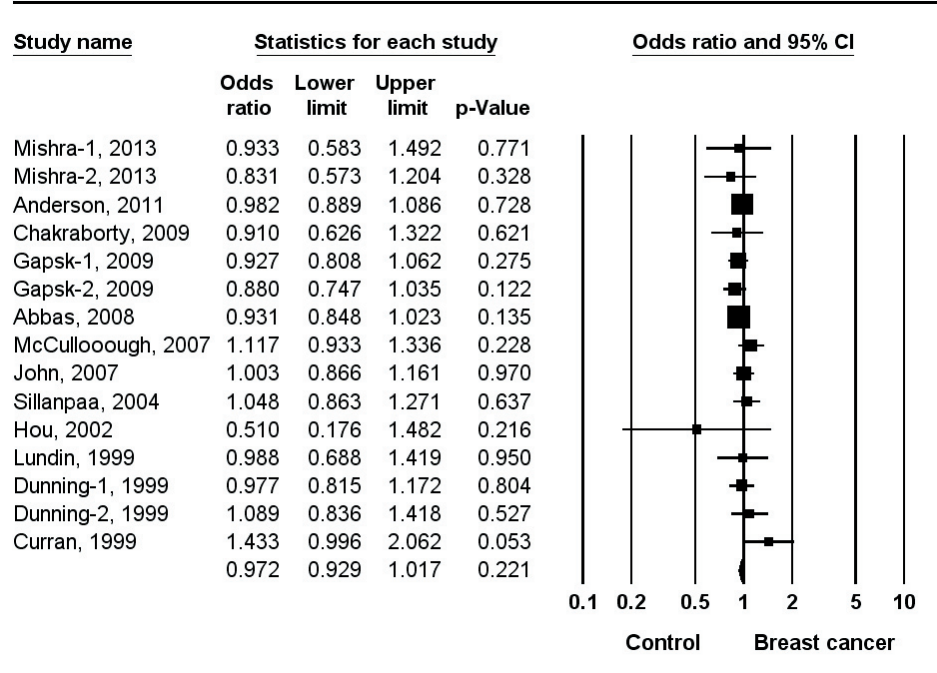

Figure 3. ORs and $95 \%$ CIs of individual studies and pooled data for the association between breast cancer incidence and the VDR BsmI (A), ApaI (B) and TaqI (C) polymorphisms, under the recessive model. 
Table 3. Meta-analysis of the association between breast cancer incidence and the VDR and BsmI, ApaI and TaqI polymorphisms.

\begin{tabular}{|c|c|c|c|c|c|c|c|c|}
\hline \multirow[t]{2}{*}{ Polymorphism } & \multirow[t]{2}{*}{ Population } & \multirow{2}{*}{$\begin{array}{l}\text { No. of stud- } \\
\text { ies }\end{array}$} & \multicolumn{3}{|c|}{ Test of association } & \multicolumn{3}{|c|}{ Test of heterogeneity } \\
\hline & & & OR & $95 \% \mathrm{CI}$ & $p$-val & Model & $p$-val & $I^{2}$ \\
\hline \multirow{2}{*}{ BsmI B vs. b } & Overall & 15 & 0.996 & $0.964-1.097$ & 0.930 & $\mathrm{R}$ & 0.000 & 68.8 \\
\hline & European & 10 & 1.026 & $0.929-1.134$ & 0.610 & $\mathrm{R}$ & 0.001 & 68.3 \\
\hline \multirow{2}{*}{$\mathrm{BB}$ vs. $\mathrm{Bb}+\mathrm{bb}$ (recessive) } & Overall & 15 & 0.952 & $0.869-1.043$ & 0.289 & $\mathrm{~F}$ & 0.170 & 25.7 \\
\hline & European & 10 & 0.980 & $0.889-1.081$ & 0.690 & $\mathrm{~F}$ & 0.570 & 0 \\
\hline \multirow{2}{*}{$\mathrm{BB}+\mathrm{Bb}$ vs. bb (dominant) } & Overall & 15 & 1.016 & $0.950-1.086$ & 0.643 & $\mathrm{R}$ & 0.000 & 69.2 \\
\hline & European & 10 & 1.042 & $0.893-1.217$ & 0.600 & $\mathrm{R}$ & 0.000 & 73.4 \\
\hline \multirow{2}{*}{ BB vs. bb } & Overall & 15 & 0.967 & $0.813-1.149$ & 0.700 & $\mathrm{R}$ & 0.005 & 55.1 \\
\hline & European & 10 & 1.028 & $0.870-1.215$ & 0.748 & $\mathrm{R}$ & 0.037 & 49.5 \\
\hline \multirow{2}{*}{ ApaI A vs. a } & Overall & 8 & 0.908 & $0.763-1.041$ & 0.167 & $\mathrm{R}$ & 0.018 & 58.5 \\
\hline & European & 5 & 0.934 & 0.818-1.067 & 0.317 & $\mathrm{R}$ & 0.055 & 56.8 \\
\hline \multirow{2}{*}{$\begin{array}{l}\text { AA vs. Aa + aa } \\
\text { (recessive) }\end{array}$} & Overall & 8 & 0.948 & $0.850-1.057$ & 0.334 & $\mathrm{~F}$ & 0.127 & 37.9 \\
\hline & European & 5 & 0.877 & $0.708-1.086$ & 0.229 & $\mathrm{R}$ & 0.041 & 59.9 \\
\hline \multirow{2}{*}{$\begin{array}{l}\text { AA + Aa vs. aa } \\
\text { (dominant) }\end{array}$} & Overall & 8 & 0.860 & $0.659-1.121$ & 0.264 & $\mathrm{R}$ & 0.076 & 64.2 \\
\hline & European & 5 & 1.001 & $0.881-1.138$ & 0.985 & $\mathrm{~F}$ & 0.371 & 6.20 \\
\hline \multirow{2}{*}{ AA vs. aa } & Overall & 8 & 0.964 & $0.834-1.114$ & 0.619 & $\mathrm{~F}$ & 0.143 & 35.8 \\
\hline & European & 5 & 0.898 & $0.697-1.158$ & 0.407 & $\mathrm{R}$ & 0.085 & 51.1 \\
\hline \multirow[t]{2}{*}{ TaqI T vs. $\mathrm{t}$} & Overall & 15 & 0.972 & $0.929-1.017$ & 0.221 & $\mathrm{~F}$ & 0.515 & 0 \\
\hline & European & 10 & 0.974 & $0.928-1.023$ & 0.294 & $\mathrm{~F}$ & 0.296 & 16.0 \\
\hline \multirow{2}{*}{$\mathrm{TT}$ vs. $\mathrm{Tt}+\mathrm{tt}$ (recessive) } & Overall & 15 & 0.970 & $0.910-1.034$ & 0.354 & $\mathrm{~F}$ & 0.788 & 0 \\
\hline & European & 10 & 0.959 & $0.895-1.029$ & 0.247 & $\mathrm{~F}$ & 0.740 & 0 \\
\hline \multirow{2}{*}{$\mathrm{TT}+\mathrm{Tt}$ vs. $\mathrm{tt}$ (dominant) } & Overall & 15 & 0.953 & $0.873-1.039$ & 0.276 & $\mathrm{~F}$ & 0.185 & 24.9 \\
\hline & European & 10 & 0.979 & $0.893-1.073$ & 0.645 & $\mathrm{~F}$ & 0.171 & 29.8 \\
\hline \multirow{2}{*}{ TT vs. tt } & Overall & 15 & 0.929 & $0.844-1.023$ & 0.136 & $\mathrm{~F}$ & 0.320 & 12.1 \\
\hline & European & 10 & 0.947 & $0.855-1.050$ & 0.303 & $\mathrm{~F}$ & 0.196 & 26.9 \\
\hline
\end{tabular}

$V D R$, vitamin D receptor; $O R$, odds ratio; $C I$, confidence interval; $R$, Random effects model; $F$, Fixed effects model.

Our findings are consistent with the functional analysis of the VDR FokI polymorphism. The FokI polymorphism is located in a start codon that creates an alternative start site resulting in the synthesis of a protein of an alternate length [55]. The long variant $f$ allele is transcriptionally less active and is associated with a lower transactivation of the VDR gene than the short F allele (29). The variant protein may have a decreased capacity to inhibit cellular growth after the administration of vitamin D (29). Thus, the VDR FokI f allele may increase the risk of breast cancer.

The functional effects of the VDR BsmI, ApaI, and TaqI polymorphisms, which are all located near the $3^{\prime}$-UTR region, are not clear. However, some studies suggest that these polymorphisms may alter the polyadenylation of the VDR mRNA transcript, and thus affect mRNA stability [56]. The VDR BsmI, ApaI, and TaqI polymorphisms are in regions of strong LD. Our study did not identify any association between breast cancer and the BsmI, ApaI, and TaqI polymorphisms. The reason for this lack of association could be explained with further haplotype studies.
Our results should be interpreted with caution, as the full purpose of this analysis for each ethnic group could not be achieved due to the limited number of studies included in this meta-analysis. The importance of the VDR polymorphisms during the development of breast cancer may be dependent on specific ethnicity. However, we were able to perform an ethnicity specific meta-analysis of the VDR polymorphisms only for Europeans. It is very important to substantially increase this number so that subgroup analysis for various ethnic populations can be performed. This information will increase the depth of meta-analysis and add new information to the existing field. Furthermore, meta-analysis ORs for FokI polymorphism were very modest, ranging from 1.057 to 1.141 .

The study differs in scope from a previous meta-analysis performed by Tang et al. [57], which examined the association between the VDR polymorphism and breast cancer. In the present analysis, 10 more studies, 8,831 more patients, and 9,989 more controls were included [8-17]. Nevertheless, the findings of this meta-analysis, indicating the contribution of 
A

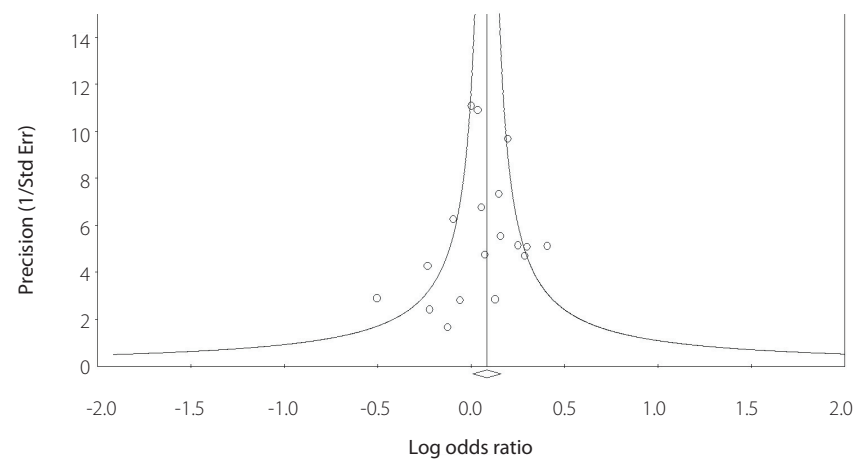

C

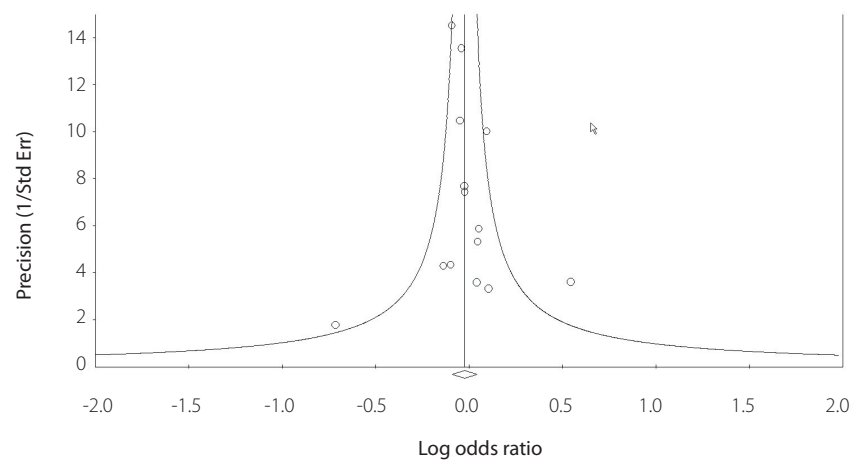

B

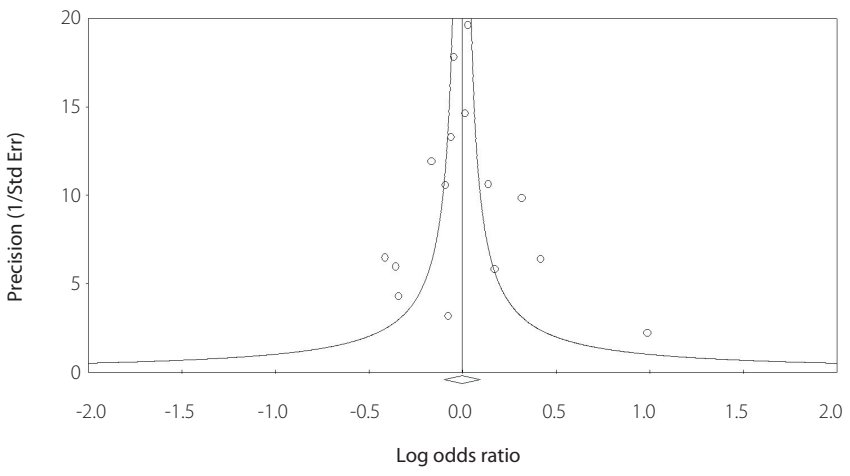

D

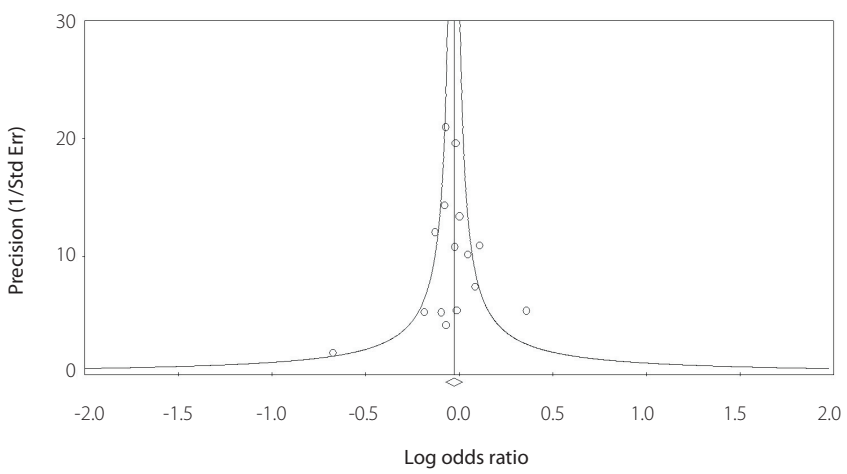

Figure 4. Funnel plot of studies analyzed for the association between breast cancer incidence and the VDR FokI (A), BsmI (B), ApaI (C) and TaqI (D) polymorphisms (Egger's regression $p$-values $=0.657,0.891,0.484$, and 0.740 , respectively).

VDR FokI f allele to the development of breast cancer, are in agreement with the previous study.

The present study has some limitations that needs to be taken into account while interpreting its findings. First, patient heterogeneity and confounding factors may have distorted the analysis. Second, haplotype analysis may have provided more information and would have been more powerful than single polymorphism analysis. Furthermore, LD was found for the BsmI, TaqI, and ApaI polymorphisms [7], however, no meta-analysis of haplotypes was possible due to inadequate haplotype data. Third, the VDR polymorphisms may be associated with breast cancer severity, but the limited amount of available data did not allow us to investigate this association.

In conclusion, this meta-analysis demonstrates that the VDR FokI polymorphism is associated with the susceptibility to breast cancer in the European population, suggesting that the VDR polymorphisms may play an important role in breast carcinogenesis. However, a similar association was not found between the VDR BsmI, ApaI, and TaqI polymorphisms and the incidence of breast cancer in the Europeans. Large-scale studies in populations that include different ethnicities are necessary to explore the roles of the VDR gene polymorphisms in the pathogenesis of breast cancer.
Acknowledgements: This research received no specific grant from any funding agency in the public, commercial, or not-for-profit sectors.

\section{References}

[1] MAVADDAT N, ANTONIOU AC, EASTON DF, GARCIA-CLOSAS M Genetic susceptibility to breast cancer. Mol Oncol 2010; 4: 174-191. http://dx.doi.org/10.1016/ j.molonc.2010.04.011

[2] Maruotti N, CANTATORE FP Vitamin D and the immune system. J Rheumatol 2010; 37: 491-495. http://dx.doi. org/10.3899/jrheum.090797

[3] BOONSTRA A, BARRAT FJ, CRAIN C, HEATH VL, SAVELKOUL HF et al. 1alpha,25-Dihydroxyvitamin d3 has a direct effect on naive CD4(+) T cells to enhance the development of Th2 cells. J Immunol 2001; 167: 4974-4980. http://dx.doi.org/10.4049/jimmunol.167.9.4974

[4] VILLENA-HEINSEN C, MEYBERG R, AXT-FLIEDNER R, REITNAUER K, REICHRATH J et al. Immunohistochemical analysis of 1,25-dihydroxyvitamin-D3-receptors, estrogen and progesterone receptors and $\mathrm{Ki}-67$ in ovarian carcinoma. Anticancer Res 2002; 22: 2261-2267.

[5] DEEB KK, TRUMP DL, JOHNSON CS Vitamin D signalling pathways in cancer: potential for anticancer therapeutics. 
Nat Rev Cancer 2007; 7: 684-700. http://dx.doi.org/10.1038/ $\underline{\operatorname{nrc} 2196}$

[6] MIYAMOTO K, KESTERSON RA, YAMAMOTO H, TAKETANI Y, NISHIWAKI E et al. Structural organization of the human vitamin D receptor chromosomal gene and its promoter. Mol Endocrinol 1997; 11: 1165-1179. http://dx.doi. org/10.1210/mend.11.8.9951

[7] MORRISON NA, YEOMAN R, KELLY PJ, EISMAN JA Contribution of trans-acting factor alleles to normal physiological variability: vitamin D receptor gene polymorphism and circulating osteocalcin. Proc Natl Acad Sci U S A 1992; 89: 6665-6669. http://dx.doi.org/10.1073/pnas.89.15.6665

[8] MISHRA DK, WU Y, SARKISSYAN M, SARKISSYAN S, $\mathrm{CHEN} Z$ et al. Vitamin D receptor gene polymorphisms and prognosis of breast cancer among African-American and Hispanic women. PLoS One 2013; 8: e57967. http://dx.doi. org/10.1371/journal.pone.0057967

[9] FUHRMAN BJ, FREEDMAN DM, BHATTI P, DOODY MM, FU YP et al. Sunlight, polymorphisms of vitamin D-related genes and risk of breast cancer. Anticancer Res 2013; 33: 543-551.

[10] SHAHBAZI S, ALAVI S, MAJIDZADEH AK, GHAFFARPOUR M, SOLEIMANI A et al. BsmI but not FokI polymorphism of VDR gene is contributed in breast cancer. Med Oncol 2013; 30: 393. http://dx.doi.org/10.1007/s12032012-0393-7

[11] ENGEL LS, ORLOW I, SIMA CS, SATAGOPAN J, MUJUMDAR U et al. Vitamin D receptor gene haplotypes and polymorphisms and risk of breast cancer: a nested case-control study. Cancer Epidemiol Biomarkers Prev 2012; 21: 18561867. http://dx.doi.org/10.1158/1055-9965.EPI-12-0551

[12] DALESSANDRI KM, MIIKE R, WIENCKE JK, FARREN G, PUGH TW et al. Vitamin D receptor polymorphisms and breast cancer risk in a high-incidence population: a pilot study. J Am Coll Surg 2012; 215: 652-657. http://dx.doi. org/10.1016/j.jamcollsurg.2012.06.413

[13] ROLLISON DE, COLE AL, TUNG KH, SLATTERY ML, BAUMGARTNER KB et al. Vitamin D intake, vitamin D receptor polymorphisms, and breast cancer risk among women living in the southwestern U.S. Breast Cancer Res Treat 2012; 132: 683-691. http://dx.doi.org/10.1007/s10549011-1885-4

[14] ANDERSON LN, COTTERCHIO M, COLE DE, KNIGHT JA Vitamin D-related genetic variants, interactions with vitamin D exposure, and breast cancer risk among Caucasian women in Ontario. Cancer Epidemiol Biomarkers Prev 2011; 20: 1708-1717. http://dx.doi.org/10.1158/1055-9965.EPI-11$\underline{0300}$

[15] CHAKRABORTY A, MISHRA AK, SONI A, REGINA T, MOHIL R et al. Vitamin D receptor gene polymorphism(s) and breast cancer risk in north Indians. Cancer Detect Prev 2009; 32: 386-394. http://dx.doi.org/10.1016/j.canep.2009.04.012

[16] GAPSKA P, SCOTT RJ, SERRANO-FERNANDEZ P, HUZARSKI T, BYRSKI $\mathrm{T}$ et al. Vitamin $\mathrm{D}$ receptor variants and breast cancer risk in the Polish population. Breast Cancer Res Treat 2009; 115: 629-633. http://dx.doi.org/10.1007/s10549008-0107-1
[17] MCKAY JD, MCCULLOUGH ML, ZIEGLER RG, KRAFT P, SALTZMAN BS et al. Vitamin D receptor polymorphisms and breast cancer risk: results from the National Cancer Institute Breast and Prostate Cancer Cohort Consortium. Cancer Epidemiol Biomarkers Prev 2009; 18: 297-305. http://dx.doi. org/10.1158/1055-9965.EPI-08-0539

[18] SINOTTE M, ROUSSEAU F, AYOTTE P, DEWAILLY E, DIORIO C et al. Vitamin D receptor polymorphisms (FokI, BsmI) and breast cancer risk: association replication in two case-control studies within French Canadian population. Endocr Relat Cancer 2008; 15: 975-983. http://dx.doi. org/10.1677/ERC-08-0056

[19] ABBAS S, NIETERS A, LINSEISEN J, SLANGER T, KROPP S et al. Vitamin D receptor gene polymorphisms and haplotypes and postmenopausal breast cancer risk. Breast Cancer Res 2008; 10: R31. http://dx.doi.org/10.1186/bcr1994

[20] MCCULLOUGH ML, STEVENS VL, DIVER WR, FEIGELSON HS, RODRIGUEZ C et al. Vitamin D pathway gene polymorphisms, diet, and risk of postmenopausal breast cancer: a nested case-control study. Breast Cancer Res 2007; 9: R9. http://dx.doi.org/10.1186/bcr1642

[21] JOHN EM, SCHWARTZ GG, KOO J, WANG W, INGLES SA Sun exposure, vitamin D receptor gene polymorphisms, and breast cancer risk in a multiethnic population. Am J Epidemiol 2007; 166: 1409-1419. http://dx.doi.org/10.1093/ aje/kwm259

[22] LOWE LC, GUY M, MANSI JL, PECKITT C, BLISS J et al. Plasma 25-hydroxy vitamin D concentrations, vitamin D receptor genotype and breast cancer risk in a UK Caucasian population. Eur J Cancer 2005; 41: 1164-1169. http://dx.doi. org/10.1016/j.ejca.2005.01.017

[23] CHEN WY, BERTONE-JOHNSON ER, HUNTER DJ, WILLETT WC, HANKINSON SE Associations between polymorphisms in the vitamin D receptor and breast cancer risk. Cancer Epidemiol Biomarkers Prev 2005; 14: 2335-2339. http://dx.doi.org/10.1158/1055-9965.EPI-05-0283

[24] SILLANPAA P, HIRVONEN A, KATAJA V, ESKELINEN M, KOSMA VM et al. Vitamin D receptor gene polymorphism as an important modifier of positive family history related breast cancer risk. Pharmacogenetics 2004; 14: 239-245. http://dx.doi.org/10.1097/00008571-200404000-00003

[25] GUY M, LOWE LC, BRETHERTON-WATT D, MANSI JL, PECKITT C et al. Vitamin D receptor gene polymorphisms and breast cancer risk. Clin Cancer Res 2004; 10: 5472-5481. http://dx.doi.org/10.1158/1078-0432.CCR-04-0206

[26] BUYRU N, TEZOL A, YOSUNKAYA-FENERCI E, DALAY $\mathrm{N}$ Vitamin D receptor gene polymorphisms in breast cancer. Exp Mol Med 2003; 35: 550-555. http://dx.doi.org/10.1038/ emm.2003.72

[27] HOU MF, TIEN YC, LIN GT, CHEN CJ, LIU CS et al. Association of vitamin D receptor gene polymorphism with sporadic breast cancer in Taiwanese patients. Breast Cancer Res Treat 2002; 74: 1-7. http://dx.doi.org/10.1023/A:1016048900049

[28] INGLES SA, GARCIA DG, WANG W, NIETERS A, HENDERSON BE et al. Vitamin D receptor genotype and breast cancer in Latinas (United States). Cancer Causes Control 2000; 11: 25-30. http://dx.doi.org/10.1023/A:1008979417618 
[29] LUNDIN AC, SODERKVIST P, ERIKSSON B, BERGMANJUNGESTROM M, WINGREN S Association of breast cancer progression with a vitamin D receptor gene polymorphism. South-East Sweden Breast Cancer Group. Cancer Res 1999; 59: 2332-2334.

[30] DUNNING AM, MCBRIDE S, GREGORY J, DUROCHER F, FOSTER NA et al. No association between androgen or vitamin $\mathrm{D}$ receptor gene polymorphisms and risk of breast cancer. Carcinogenesis 1999; 20: 2131-2135. http://dx.doi. org/10.1093/carcin/20.11.2131

[31] CURRAN JE, VAUGHAN T, LEA RA, WEINSTEIN SR, MORRISON NA et al. Association of A vitamin D receptor polymorphism with sporadic breast cancer development. Int J Cancer 1999; 83: 723-726. http://dx.doi. org/10.1002/(SICI) 1097-0215(19991210)83:6<723::AIDIJC4>3.0.CO;2-3

[32] NATH SK, HARLEY JB, LEE YH Polymorphisms of complement receptor 1 and interleukin-10 genes and systemic lupus erythematosus: a meta-analysis. Hum Genet 2005; 118: 225-234. http://dx.doi.org/10.1007/s00439-005-0044-6

[33] LEE YH, WITTE T, MOMOT T, SCHMIDT RE, KAUFMAN $\mathrm{KM}$ et al. The mannose-binding lectin gene polymorphisms and systemic lupus erythematosus: two case-control studies and a meta-analysis. Arthritis Rheum 2005; 52: 3966-3974. http://dx.doi.org/10.1002/art.21484

[34] LEE YH, Ji JD, SONG GG Tumor necrosis factor-alpha promoter $-308 \mathrm{~A} / \mathrm{G}$ polymorphism and rheumatoid arthritis susceptibility: a metaanalysis. J Rheumatol 2007; 34: 43-49.

[35] HIGGINS JP, THOMPSON SG Quantifying heterogeneity in a meta-analysis. Stat Med 2002; 21: 1539-1558. http://dx.doi. org/10.1002/sim.1186

[36] Egger M, Smith GD, PHILLIPS AN Meta-analysis: principles and procedures. BMJ 1997; 315: 1533-1537. http://dx.doi. org/10.1136/bmj.315.7121.1533

[37] DERSIMONIAN R, LAIRD N Meta-analysis in clinical trials. Control Clin Trials 1986; 7: 177-188. http://dx.doi. org/10.1016/0197-2456(86)90046-2

[38] EGGER M, DAVEY SMITH G, SCHNEIDER M, MINDER C Bias in meta-analysis detected by a simple, graphical test. BMJ 1997; 315: 629-634. http://dx.doi.org/10.1136/ bmj.315.7109.629

[39] MOSTOWSKA A, SAJDAK S, PAWLIK P, LIANERI M, JAGODZINSKI PP Vitamin D receptor gene BsmI and FokI polymorphisms in relation to ovarian cancer risk in the Polish population. Genet Test Mol Biomarkers 2013; 17: 183-187. http://dx.doi.org/10.1089/gtmb.2012.0332

[40] LURIE G, WILKENS LR, THOMPSON PJ, CARNEY ME, PALMIERI RT et al. Vitamin D receptor rs2228570 polymorphism and invasive ovarian carcinoma risk: pooled analysis in five studies within the Ovarian Cancer Association Consortium. Int J Cancer 2011; 128: 936-943. http://dx.doi. org/10.1002/ijc.25403

[41] TWOROGER SS, GATES MA, LEE IM, BURING JE, TITUSERNSTOFF L et al. Polymorphisms in the vitamin D receptor and risk of ovarian cancer in four studies. Cancer Res 2009; 69: 1885-1891. http://dx.doi.org/10.1158/0008-5472.CAN08-3515
[42] LURIE G, WILKENS LR, THOMPSON PJ, MCDUFFIE $\mathrm{KE}, \mathrm{CARNEY} \mathrm{ME}$ et al. Vitamin D receptor gene polymorphisms and epithelial ovarian cancer risk. Cancer Epidemiol Biomarkers Prev 2007; 16: 2566-2571. http://dx.doi.org/ 10.1158/1055-9965.EPI-07-0753

[43] CLENDENEN TV, ARSLAN AA, KOENIG KL, ENQUIST K, WIRGIN I et al. Vitamin D receptor polymorphisms and risk of epithelial ovarian cancer. Cancer Lett 2008; 260: 209-215. http://dx.doi.org/10.1016/j.canlet.2007.11.002

[44] KOSTNER K, DENZER N, MULLER CS, KLEIN R, TILGEN $\mathrm{W}$ et al. The relevance of vitamin $\mathrm{D}$ receptor (VDR) gene polymorphisms for cancer: a review of the literature. Anticancer Res 2009; 29: 3511-3536.

[45] AHN J, ALBANES D, BERNDT SI, PETERS U, CHATTERJEE $\mathrm{N}$ et al. Vitamin D-related genes, serum vitamin D concentrations and prostate cancer risk. Carcinogenesis 2009; 30: 769-776. http://dx.doi.org/10.1093/carcin/bgp055

[46] PETERS U, HAYES RB, CHATTERJEE N, SHAO W, SCHOEN $\mathrm{RE}$ et al. Circulating vitamin D metabolites, polymorphism in vitamin D receptor, and colorectal adenoma risk. Cancer Epidemiol Biomarkers Prev 2004; 13: 546-552.

[47] TAMEZ S, NORIZOE C, OCHIAI K, TAKAHASHI D, SHIMOJIMA A et al. Vitamin D receptor polymorphisms and prognosis of patients with epithelial ovarian cancer. $\mathrm{Br}$ J Cancer 2009; 101: 1957-1960. http://dx.doi.org/10.1038/ sj.bjc. 6605414

[48] TRABERT B, MALONE KE, DALING JR, DOODY DR, BERNSTEIN L et al. Vitamin D receptor polymorphisms and breast cancer risk in a large population-based case-control study of Caucasian and African-American women. Breast Cancer Res 2007; 9: R84. http://dx.doi.org/10.1186/bcr1833

[49] VANDEVORD PJ, WOOLEY PH, DARGA LL, SEVERSON RK, WU B et al. Genetic determinants of bone mass do not relate with breast cancer risk in US white and African-American women. Breast Cancer Res Treat 2006; 100: 103-107. http://dx.doi.org/10.1007/s10549-006-9228-6

[50] HEFLER LA, TEMPFER CB, GRIMM C, LEBRECHT A, UL$\mathrm{BRICH} \mathrm{E}$ et al. Estrogen-metabolizing gene polymorphisms in the assessment of breast carcinoma risk and fibroadenoma risk in Caucasian women. Cancer 2004; 101: 264-269. http:// dx.doi.org/10.1002/cncr.20361

[51] RUGGIERO M, PACINI S, ATERINI S, FALLAI C, RUGGIERO C et al. Vitamin D receptor gene polymorphism is associated with metastatic breast cancer. Oncol Res 1998; 10: $43-46$.

[52] YAO S, ZIRPOLI G, BOVBJERG DH, JANDORF L, HONG $\mathrm{CC}$ et al. Variants in the vitamin D pathway, serum levels of vitamin $\mathrm{D}$, and estrogen receptor negative breast cancer among African-American women: a case-control study. Breast Cancer Res 2012; 14: R58. http://dx.doi.org/10.1186/bcr3162

[53] BARROSO E, FERNANDEZ LP, MILNE RL, PITA G, SENDAGORTA E et al. Genetic analysis of the vitamin D receptor gene in two epithelial cancers: melanoma and breast cancer case-control studies. BMC Cancer 2008; 8: 385. http://dx.doi. org/10.1186/1471-2407-8-385

[54] RAIMONDI S, JOHANSSON H, MAISONNEUVE P, GANDINI S Review and meta-analysis on vitamin D recep- 
tor polymorphisms and cancer risk. Carcinogenesis 2009; 30: 1170-1180. http://dx.doi.org/10.1093/carcin/bgp103

[55] ARAI H, MIYAMOTO K, TAKETANI Y, YAMAMOTO H, IEMORI Y et al. A vitamin D receptor gene polymorphism in the translation initiation codon: effect on protein activity and relation to bone mineral density in Japanese women. J Bone Miner Res 1997; 12: 915-921. http://dx.doi.org/10.1359/ jbmr.1997.12.6.915
[56] UITTERLINDEN AG, FANG Y, VAN MEURS JB, POLS HA, VAN LEEUWEN JP Genetics and biology of vitamin D receptor polymorphisms. Gene 2004; 338: 143-156. http://dx.doi. org/10.1016/i.gene.2004.05.014

[57] TANG C, CHEN N, WU M, YUAN H, DU Y Fok1 polymorphism of vitamin $\mathrm{D}$ receptor gene contributes to breast cancer susceptibility: a meta-analysis. Breast Cancer Res Treat 2009; 117: 391-399. http://dx.doi.org/10.1007/s10549-008-0262-4 